\title{
KRT18 Gene
}

National Cancer Institute

\section{Source}

National Cancer Institute. KRT18 Gene. NCI Thesaurus. Code C111866.

This gene plays a role in keratin filament structure. 